Hundreds of puparia have frequently been found in the soil around a single sugar-beet which means that large numbers of root lice have been destroyed. The larva is particularly efficient in that it concentrates its efforts on destroying only well developed root lice, thus preventing the birth of young root lice that would soon increase to enormous numbers. It is not uncommon to find a large number of puparia in the soil around a sugar-beet plant with only the empty skins and secretions of the root lice to indicate their former abundance.

It is certain that $C$. glabra larvæ act as a very important check upon the increase of sugar-beet root lice and in many instances destroy entire colonies.

\title{
NEW GALL MIDGES (DIPT.)
}

By E. P. Feut, Albany, N. Y.

The species described below comprise some unusual forms, especially the presumably predaceous Mycodiplosis packardi, which closely simulates the associated Retinodiplosis albitarsis, the latter with a most interesting larva. The types are in the New York State Museum.

Allomyia n. g. The presence of circumfili, toothed claws, a third vein uniting with costa at the apex of the wing, triarticulate palpi and thirteen antennal segments, indicates a relationship with Cystiphora Kieff., from which the genus can be easily separated by the absence of a terminal spine on the short ovipositor. Type A. juniperi $n$. sp.

Allomyia JUNIPERI $\mathrm{n}$. sp. The one female issued June 12, 1918, from a package of apical, burr-like galls on Juniperus received June 5, 1918 from Ivan M. Way, Oxford, Colo.

The gall is a small, apical, burr-like deformity with a diameter of $5 \mathrm{~mm}$. It differs from the larger rosette galls in that there are no distinctly reflexed leaves.

Female. Length $1.5 \mathrm{~mm}$. Antennæ extending to the base of the abdomen, sparsely haired, mostly yellowish and reddish, thirteen sessile segments, the fifth with a length two and one-half times its diameter, a subbasal irregular whorl of long, stout setæ and at the basal third and apically low, fine, indistinct circumfili. Terminal segment produced, with a length over three times its diameter, the apex subacute. Palpi; first segment rectangular, the second quadrate, the third narrowly oval, the second and third with a series of stout, spiny processes apically. Mesonotum dark brown, almost black. Scutellum dark reddish brown, margined with dark brown. Postscutellum dark yellowish orange. Abdomen dark brown, the short ovipositor yellowish orange. Wings hyaline, subcosta uniting with the anterior margin near the basal half, the third vein, strongly curved distally, at the apex of the wing, the fifth probably forked. Halteres pale yellowish. Legs mostly pale straw, the distal portion of tibize and the tarsi dark reddish. The one claw on the posterior leg of the specimen is unusually stout, strongly curved, unidentate and the pul- 
villi is greatly produced, having a length nearly thrice that of the claw and a width greater than the length of the claw. Ovipositor short, the lobes broad, roundly truncate and thickly clothed with short, stout, spiny hairs. Type Cecid. a 2921.

Asphondylia DONDise n. sp. The male described below was reared from deformed leaves on sea blite, Suoda or Dondia multiflora, collected by Professor E. Bethel, April, 1918, at Point Fermine, Calif. It is related to $A$. vernonice Felt and $A$. ceanothi Felt from which it is most easily separated by color characters and variations in the length of the third antennal and palpal segments.

The gall is a blackish, globose, sessile, leafy deformation with a diameter of $3 \mathrm{~mm}$.

LARvA. Length $1.75 \mathrm{~mm}$. Stout, yellowish orange, head short, broad, antennæ short, broadly triangular, biarticulate, the terminal segment with a length nearly equal to its diameter. Breastbone quadridentate, the anterior portion with a width nearly double the posterior part, skin coarsely shagreened, posterior extremity broadly rounded.

Exuvium. Length $3 \mathrm{~mm}$. Moderately stout, reddish brown and with characteristicly developed rows of spines on the dorsum of the abdominal segments.

MALE. Length $3.5 \mathrm{~mm}$. Antenna nearly as long as the body, sparsely haired, dark brown, fourteen segments, the third with a length five times its diameter. Terminal segment with a length about four times its diameter and tapering slightly to a broadly rounded apex. Palpi, first segment short, broad, the second about one-half longer than the first, the third more slender, fourth nearly as long as the third. Mesonotum dark brown, the submedian lines thickly clothed with long, white hairs. Scutellum yellowish brown with exceptionally long, whitish hairs. Postscutellum reddish orange. Abdomen dark reddish brown, sparsely clothed with yellowish hairs. Wings almost subhyaline, the membrane with a fuscous tinge. Halteres reddish orange, fuscous subapically. Coxæ dark brown, legs mostly dark straw, the tarsi nearly black. Claws rather slender, strongly curved, the pulvilli a little shorter than the claws. Genitalia; basal clasp segment short, stout, terminal clasp segment greatly reduced, almost unidentate, dorsal plate short, broad, broadly and triangularly emarginate, the short lobes partly rounded. Ventral plate short, broadly and roundly emarginate, the lobes acute, both plates thickly setose. Type Cecid. a 2892.

TheCodiplosis COCKERELLI n. sp. The gall of this insect, or at least one nearly indistinguishable therefrom, was received from Glen Eyrie, Colorado Springs, Colo., through Professor T. D. A. Cockerell, in December, 1907. Specimens were received from Ivan Way, Oxford, Colo., from which a female was reared in 1918. The species is probably generally distributed in Colorado at least.

The gall is an irregular, kidney-shaped enlargement of the needles of Pinus edulis. It has a length of $7 \mathrm{~mm}$, a diameter of $4 \mathrm{~mm}$; the walls are thick and the needles rudimentary.

Female. Length $1.75 \mathrm{~mm}$. Antennæ extending to the base of the abdomen, sparsely haired, fuscous yellowish, fourteen segments, the fifth with a stem one-fourth the length of the cylindric basal enlargement, which latter has a length two and onehalf times its diameter. Terminal segment somewhat reduced, the basal enlarge- 
ment with a length twice its diameter and apically a short, knob-like process. Palpi; first segment irregularly oval, stout, the second a little shorter, more slender, the third a little longer than the second, and the fourth slender, more than twice the length of the third. Mesonotum, scutellum and postscutellum yellowish brown. Abdomen yellowish orange. Halteres whitish transparent, legs mostly pale straw, claws of the hind legs at least, long and moderately stout, strongly curved, the pulvilli a little longer than the claws. Ovipositor when extended nearly as long as the body, distinctly chitinized, subaciculate. The distal portion is rather stout, strongly striate and apically with approximate, triangular, finely dentate lobes, each bearing at the distal fourth two diverging spike-like spines. Type Cecid. a 2822.

Mycodiplosis PACKARdi n. sp. The male of this species was reared June 20, 1918, from a white pine (Pinus strobus) branch one and onehalf inches in diameter infested with Parharmonia pini Kell. The exuded masses of pitch were inhabited by midge larvæ, some of which remained in the pitch, transformed therein and produced adults described as Retinodiplosis albitarsis n. sp. There were other larvæ which emerged from the pitch mass and formed cocoons either on the twigs or the bottom of the tree and it is apparently from these other larvæ that this species was reared. The habit of deserting the pitch and making cocoons upon the food plant appears to be identical with that described for Cecidomyia pini-rigidee Packard and there is a possibility that the two are identical, though this cannot be determined with the data available.

Cocoon. Length $5 \mathrm{~mm}$, diameter $2 \mathrm{~mm}$. Moderately stout, mostly indistinctly rounded, the pointed apex presenting the appearance of a rather short, stout, waxy process.

MaLE. Length $3 \mathrm{~mm}$. Antenne probably nearly as long as the body, rather thickly haired, fuscous yellowish, fourteen segments, the fifth almost trinodose with stems one and one-fourth and twice their lengths respectively. Basal enlargement globose, the distal enlargement, strongly constricted near the middle with a length almost twice its diameter, the loops of the circumfili moderately numerous and with a length greater than the diameter of the enlargement. Terminal segment having the basal portion of the stem with a length one-half greater than its diameter, the distal enlargement so strongly constricted near the basal third as to suggest two partly adherent spheres and apically a short stem bearing a small subglobose appendage. Palpi; first segment quadrate, the second with a length twice the first, the third slender and with a length one-half greater than the second and the fourth as long as the second, slender. Mesonotum dark brown, with moderately thickly haired submedian lines. Scutellum and postscutellum dark brown. Abdomen sparsely haired, dark brown. Wings subhyaline, the membrane thickly clothed with fuscous hairs. Halteres yellowish basally, fuscous apically. Coxæ fuscous yellowish. Legs mostly dark brown. Claws long, slender, rather strongly curved, the anterior unidentate, the pulvilli about one-half the length of the claws. Genitalia; basal clasp segment rather long, stout; terminal clasp segment a little longer than the basal, slender. Dorsal plate short, very deeply and triangularly emarginate, the lobes narrowly triangular and sparsely setose apically. Ventral plate moderately long, broad, deeply and roundly emarginate, the lobes rather broad, narrowly rounded apically and with a stout seta at the tip. Style long, stout, narrowly rounded apically. 
This species runs in the key to M. emarginata Felt, from which it is easily separated by both colorational and structural characters. It presents a remarkable similarity to Retinodiplosis with which it is evidently associated and upon which it may prey. The two species, under a hand lens, appeared almost indistinguishable, except that the Mycodiplosis was somewhat smaller. The color characters of this midge are partly conjectural. Type Cecid a $2917 \mathrm{a}$. Named in honor or of Doctor A. S. Packard, one of the first American Entomologists to study the gall midge fauna of our pines.

Retinodiplosis albitarsis n. sp. A series of both sexes was reared in June, 1918, from a white pine (Pinus strobus) branch one and onehalf inches in diameter, infested with Parharmonia pini Kell. The exuded masses of pitch were inhabited by midge larvæ which transformed therein and produced large sized, dark colored adults with very constant, striking tarsal markings. The very similar Mycodiplosis packardi was also reared, the larva of this latter apparently deserting the pitch masses prior to transforming. This Retinodiplosis has the general structural and color characters of $R$. palustris Felt, from which it is most easily distinguished by the distinct narrow femoral and tibial white annulations and yellowish white distal three tarsal segments of the posterior legs.

MALE. Length $3 \mathrm{~mm}$. Antennæ two-thirds the length of the body, fuscous yellowish or dark brown, fourteen segments, the fifth having stems as long and one-half longer than their diameters respectively, the basal enlargement subglobose, the distal enlargement with a length one-fourth greater than its diameter, vasiform. The circumfili with moderately long, rather abundant stout loops. Terminal segment produced, the basal stem with a length twice its diameter, the distal enlargement produced, with a length over twice its diameter and apically with a small conical appendage. Palpi; first segment short, irregular, the second with a length three times its diameter, the third a little longer than the second, the fourth nearly as long as the third and somewhat dilated apically. Mesonotum dark reddish brown, the submedian lines thickly haired. Scutellum dark brown, apically thickly clothed with yellowish scales. Postscutellum reddish brown. Abdomen sparsely haired, deep reddish brown, genitalia fuscous, Wings thickly clothed with short; dark hairs, subfuscous. Halteres yellowish basally, fuscous subapically, whitish apically. Coxæ dark brown, femora basally fuscous yellowish, subapically fuscous, narrowly annulate with white apically. Tibiæ dark brown, narrowly annulate with white apically. Tarsi dark brown except the yellowish white distal three segments of the posterior legs. Claws moderately long, slender, curved, the pulvilli a little shorter than the claws. Genitalia; basal clasp segment moderately long, stout; terminal clasp segment rather short, stout; dorsal plate deeply and triangularly incised, the lobes irregularly triangular and narrowly rounded apically. Ventral plate rather long, moderately broad and tapering to a broadly rounded apex. Style long, stout, broadly rounded apically.

Female. Length $5 \mathrm{~mm}$. Antenna extending to the third abdominal segment, sparsely haired, fuscous yellowish, the fifth subsessile, cylindrical, with a length two and one-half times its diameter. Terminal segment somewhat produced, tapering to 
a narrowly rounded apex. Mesonotum dark brown, with moderately thick submedian lines of short, silvery scales and with the sublateral areas sparsely clothed with somewhat broader scales. Scutellum dark brown, thickly clothed with silvery scales. Postscutellum dark brown. Abdomen sparsely clothed with fuscous hairs, deep red. Halteres yellowish basally, fuscous apically. Ovipositor probably onehalf the length of the body, fuscous yellowish, the terminal lobes yellowish orange. Type Cecid. a 2917.

Larva. Length $4 \mathrm{~mm}$. Moderately long, stout, strongly segmented, with conspicuous tubercles, the extremities tapering, a variable reddish orange. Head small, subconical, the outer walls apparently slightly chitinized and at the posterio-lateral angles chitinous projections with a length twice that of the head. Antennæ slender, conical. Breastbone irregular, expanded and truncate anteriorly. The lateral and posterior spiracles on tubercles, each supported by a black chitinous, cup-shaped structure; those of the anal pair larger and strongly dentate. Abdominal segments, except the eleventh and twelfth, each with a submedian pair of long, fleshy tubercles, the length approximately one-third the body width, most of them more or less furcate. The lateral tubercles support the spiracles and are about one-fourth the length of the subdorsal tubercles. Ventrally pseudopods are fairly well developed on the tenth, eleventh and twelfth segments, those on the last spine tipped and apparently with the same structure as the subdorsal tubercles.

Onodirlosis sarcobati Felt. ${ }^{1}$ The male described below for the first time was received May 20, 1918, from Professor Harold R. Hagan, Logan, Utah, and a series of both sexes were reared from bud galls on Sarcobatus vermiculatus, the adults issuing directly from the gall after the pupa had worked itself about three-quarters out of the deformity.

MALE. Length $2.5 \mathrm{~mm}$. Antennæ a little longer than the body, sparsely haired, pale yellowish, fourteen segments, the third and fourth free, the fifth having stems each with a length about twice its diameter; the basal enlargement subglobose with a sparse subbasal whorl of stout setæ and a circumfilum with moderately short loops; the distal enlargement pyriform, with a length one-half greater than its diameter; a subbasal and subapical circumfilum, each with loops having a length less than the diameter of the enlargement; terminal segment, basal enlargement subglobose, basal portion of the stem produced, slender, the distal enlargement irregular and tapering to an obtuse apex. Palpus consisting of an irregular, tapering setose segment with a length about twice its diameter. Mesonotum dark yellowish brown. Scutellum and postscutellum very dark brown, almost black. Abdomen sparsely haired, fuscous yellowish, genitalia somewhat darker. Wings as in the female. Halteres whitish basally, fuscous yellowish apically. Coxæ dark brown, legs mostly pale straw. Genitalia; basal clasp segment stout, with a length about twice its diameter, terminal clasp segment moderately long, swollen subapically, the chitinous tip pectinate. Dorsal plate long, deeply and triangularly emarginate, the lobes broad, broadly rounded, ventral plate short, broadly emarginate, lobes broadly rounded. Harpes widely separated apically, roundly tapering and sparsely setose. Style short, chitinized apically. Cecid. a 2914.

PupA. Length $2.5 \mathrm{~mm}$. Head, thorax, antennæ, wing and leg cases all a somewhat variable fuscous yellowish. Abdomen red, smooth.

1 1916, Felt, E. P., N. Y. Ent. Soc. Journ., 24: 176. 